\title{
PROMOTING A RESPECT FOR DIFFERENCE THROUGH LANGUAGE TEACHING
}

\author{
Alistair Welsh \\ (alistair.welsh@deakin.edu.au) \\ Deakin University \\ 221 Burwood Hwy, Burwood VIC 3125, Australia
}

\begin{abstract}
An emphasis on developing students' moral and ethical character is evident in the 2013 National Indonesian Curriculum. In this article, I look at how respect for difference is reflected in the 2013 Indonesian National Curriculum, specifically referring to the second key competency area for senior high school English language. I also draw reference from academic literature that can be linked to this competency area of the English curriculum. Exploring theoretical links from the literature is useful to develop a deeper understanding of the importance of this key competency area. Discussion explores the significance of respect for difference and the important role that English language teachers in Indonesia can play in promoting tolerance. By understanding how culture can be used as a divisive force, we can more readily identify how teachers can develop a respect for difference in their students to help overcome intolerant attitudes that can lead to discrimination.
\end{abstract}

Keywords: tolerance, respect for difference, dialogism, critical thinking, national Indonesian curriculum

The 2013 Indonesian National Curriculum reflects an emphasis on character building that seeks to develop students' personal attributes in terms of moral values and ethical behaviour. To discuss how this applies to the English language curriculum, I focus on the second key competency area of the English language curriculum for senior high school. In focusing on this competency area, I do not wish to imply that moral and ethical values are not also evident elsewhere in the curriculum. However, for the purposes of this publication, it is 
the English language curriculum that is of greatest relevance. Moreover, the matter of character building through ethical and moral values is prominent in the English language curriculum, particularly in the second key competency area. English teachers are therefore expected to make a contribution to the moral and ethical values of their students. However, given the abstract and complex nature of these concepts, along with pre-existing pressures on language teachers to teach more concrete aspects of language skills such as grammar and functional usage, it is fair to expect that the requirement of having to address ethical and moral values will present great challenges for many teachers of English. It is useful to consider relevant underlying theory that can provide a deeper understanding of why it is important to include ethical and moral values in language teaching and how this might be done.

\section{THE SECOND KEY COMPETENCY AREA FOR ENGLISH}

The second key competency area of the English curriculum from the 2013 national curriculum is a key focus of this article. Before seeking to link that competency area to existing theory, it is useful to firstly look at this part of the 2013 national curriculum.

\section{Years 10 and 11}

The second key competency area for English is the same for years 10 and 11 , and the original wording is provided below ${ }^{1}$. I have translated it as follows: To develop behaviour (that is honest, disciplined, responsible, caring, polite, environmentally friendly, team oriented, co-operative, peace-loving, responsive and pro-active) and to demonstrate a disposition to be part of the solution to various national problems in effectively interacting in the social and natural

\footnotetext{
${ }^{1}$ Mengembangkan perilaku (jujur, disiplin, tanggung jawab, peduli, santun, ramah lingkungan, gotong royong, kerjasama, cinta damai, responsif dan proaktif) dan menunjukan sikap sebagai bagian dari solusi atas berbagai permasalahan bangsa dalam berinteraksi secara efektif dengan lingkungan sosial dan alam serta dalam menempatkan diri sebagai cerminan bangsa dalam pergaulan dunia. (Kementrian Pendidikan dan Kebudayaan 2013, pp. 66-68)
} 
environment and in positioning one's self as a reflection of one's nation in a global community.

\section{Year 12}

The original wording of the second key competency area for English for year 12 is provided below ${ }^{2}$. I have translated it as follows: To develop behaviour (that is honest, disciplined, responsible, caring, polite, environmentally friendly, team oriented, co-operative, peace-loving, responsive and pro-active) and to demonstrate a disposition to be part of the solution to various national problems, as well as positioning one's self as an agent of transformation for society in building a civilised nation and world.

This competency area has much in common across years 10 to 12 , including the abilities of being responsible, caring, well-mannered, co-operative in working together, peace-loving and responsive. For years 10 and 11, there is a focus on the ability to be effective in problem solving in social interactions and the ability to position one's self in such a way that reflects one's national self in a global context. A variation of this competency area for year 12 adds a higher order ability that aims to enable students to become agents of change in transforming society in building a more civilised nation and world. These are noble pursuits and are likely to be viewed by teachers as complex and challenging aims to achieve.

The competencies referred to above reflect the important broader role of education in character building and in developing critical thinking and respect for others. A challenge for language teachers is to help develop attitudes, abilities and behaviours that enable students to become good global citizens, while also reflecting a national identity. This involves developing a complex awareness of identity positions of self and other, both at an individual and collective level, a matter which I will refer to throughout this article. By recognising that

\footnotetext{
${ }^{2}$ Mengembangkan perilaku (jujur, disiplin, tanggung jawab, peduli, santun, ramah lingkungan, gotong royong, kerjasama, cinta damai, responsif dan proaktif), menunjukkan sikap sebagai bagian dari solusi atas berbagai permasalahan bangsa, serta memosisikan diri sebagai agen transformasi masyarakat dalam membangun peradaban bangsa dan dunia._Kementrian Pendidikan dan Kebudayaan 2013, p. 70)
} 
processes involved in language teaching and learning can be effective in developing a better understanding of identity positions, we can appreciate why this is reflected in the 2013 curriculum. However, merely recognising different identity positions alone does not guarantee that one will accept other identity positions. In order to examine this more closely, I will start by looking at the notion of culture and how it can shape a sense of identity of self and other.

\section{THE NOTION OF CULTURE AS A DIVISIVE FORCE}

A traditional concept of culture relates to knowing about a collective other, who are defined as being different or exotic, as described by Edward Tyler in the early twentieth century (Lo Bianco, 2009). This traditional view of culture remains evident today and often leads to the assumption that culture is a fixed, unnegotiable set of customs, traditions and social norms. This is what Liddicoat (2002) describes as a static concept of culture and is consistent with what Holliday (2011) refers to as an essentialist view of culture, that is typically defined by national, ethnic, racial or religious groupings.

Where a concept of culture is essentialised or viewed as static, it can be used as it was in colonial times to define 'others' as separate from 'us'. In this way, a traditional definition of culture can be used in a divisive manner to define social boundaries and to affect the formation of identity (Duranti, 1997). A static notion of culture readily enables one to define a sense of a collective self where characteristics are shared by a group. As part of the same process, one defines the self as separate to a cultural other through a logic of different characteristics. This is consistent with how Wenger (1998) views identity as being shaped, where self-identity is conceptualised, in part, as being the opposite of the cultural other. This means that merely having knowledge of a cultural other does not guarantee that one will identify with it, nor accept or respect it. In fact, Duranti (1997) suggests that colonialists understood characteristics of other cultural groups but used the term 'culture' to separate and dominate 'the other'. He suggests that even today the recognition of different cultural groups remains a way of explaining why minority and marginalised groups do not assimilate into mainstream society.

\section{REPRESSING DIFFERENCES OF 'THE OTHER'}

In discussing how differences between people are commonly viewed, Kristeva (1991) describes 'the other' in terms of being a stranger or foreigner. 
She argues that when people confront otherness, the self typically responds with one of two kinds of logic, either assimilation or repression. If the other is perceived as being sufficiently similar it can be seen as equal, thereby reflecting a logic of assimilation. However, if the other is perceived as being different, and if that difference cannot be assimilated, then the difference of the other is regarded as being inferior. This reflects a logic of repression (Barclay, 2010; Kristeva, 1991), where a logic of binary opposites is evident, and represented through such values as: good and bad, superior and inferior, and right and wrong. This can be seen as a common instinctive reaction towards cultural differences, particularly where there is an essentialist, static notion of culture that results in a reductionist view of the cultural other.

Some people view language learners quite negatively, where the experience of learning another language is perceived as threatening the identity of the collective self. This reflects an essentialist, binary logic of exclusivity between 'us' and 'them', where each identity position is perceived as being entirely separate identity positions. Applying such logic may lead one to accuse language learners of a lack of respect of their own country and culture, and of crossing the boundary to adopt the identity position of the other. For example, in the context of Indonesia, some people may view learners of English as being sympathetic to American political ideologies and therefore unpatriotic to Indonesia. However, such logic is based on the assumptions that cultures are static and exclusive and that to learn the language of others involves adopting their cultural values. The essentialist nature of such logic implies that all Americans share the same ideology, which is entirely different to an ideology shared by all Indonesians. Such logic reflects stereotyping and often seeks to repress the other. Clearly, not all citizens of any country entirely share the same ideology, yet this is sometimes what is implied or assumed to be the case. Such essentialist, binary logic focuses on differences and tends to overlook the human dimension of culture and the possibility of similarities between cultural groups. It also ignores the human interactive potential of intercultural spaces to dynamically combine elements of self and other.

\section{IN-BETWEEN-NESS}

To overcome a repressive reaction towards otherness, Kristeva (1991) suggests the notion of in-between-ness. She describes the self as recognising foreign traits of another culture as being evident within one's own psyche. She 
suggests that one recognise strangeness of the other not because it is foreign to the self but because it is within the self, but has been repressed. Kristeva describes the notion of a 'polymorphic' culture where people are required to take into account otherness within the self, and where 'culture' does not merely assimilate otherness but that it dissolves the clear boundaries between self and others. In this way, Kristeva conceptualises 'in-between-ness', as an intercultural space. She proposes cosmopolitanism as a way of calling us to respect and welcome the stranger within us, and therefore being able to welcome the other.

\section{BAKHTIN'S CONCEPT OF DIALOGISM}

Mikhail Bakhtin, a prominent Russian philosopher, provides some very useful theory about language. For the purposes of this discussion, Bahktin's (1981) notion of dialogism is of great interest, and has implications for how the self perceives the cultural other. According to Bakhtin's (1981) notion of dialogism, outsidedness enables one to see the individual or collective self from the outside, as others do. This is an act of critical thinking and self-reflexivity where one imagines how he or she is perceived by others. It is a productive act that allows the self to consider alternative voices and to interact with the other dynamically. Engaging outsidedness can help generate new intercultural spaces and identity positions, as we look at ourselves differently and critically.

An ethical response to otherness is not to assimilate or repress the other, but to view and interact with the other in a way that values the other, whilst not denying the self. Bakhtin's suggestion of the need to maintain one's own unique place, yet at the same time to co-experience otherness (Brandist, 2002) demonstrates the potential to have multiple identity positions. This can be viewed as consistent with the 2013 national curriculum, where the aim of students becoming global citizens can be seen as co-experiencing otherness, whilst reflecting a national identity can be seen in relative terms as retaining one's own unique place. Co-experiencing otherness can take the form of intercultural interaction, as in Bakhtin's dialogism, where two entities can retain their original or unique identities while interacting on the basis that the other and self are equal yet different. In this way, Bakhtin's dialogism represents ethical intercultural acts that recognise equality despite differences.

Dialogic acts where both self and other are afforded a voice, provide the transformational stepping stones for language learners to become what Kramsch (2009) refers to as intercultural speakers. By engaging dialogism, an 
ethical act is made possible to achieve what Kristeva (1991) refers to as inbetween-ness, that is, a generative space for transformative relations between self and other. The in-between-ness of interculturality is achieved through dialogism (Bakhtin 1981).

\section{THE ROLE OF LANGUAGE TEACHERS}

The practice of dialogic intercultural encounters in the classroom includes critical thinking, and positions the language teacher as modeller (Kramsch, 2009), as advocate for the target culture (Lo Bianco, 2009) and mediator of intercultural engagement (Liddicoat \& Kohler, 2012). Teachers do not need to be native speakers of the target language, but teachers do need to present a range of alternative 'voices' in the form of points of view, that can be regarded as representing otherness.

Mediating students' views and helping raise students' awareness of otherness can be done by providing alternative views and by modelling a world view where things are unfinalised and evolving. Holliday (2011) advocates the notion of critical cosmopolitanism, which involves a concept of culture where diversity is normal, where cultural boundaries may be unclear and dynamic, and where all sides adopt a critical outlook. This helps project a view of culture consistent with what Liddicoat (2002) refers to as dynamic and what Holliday (2011) refers to as non-essentialist. However, if teachers promote a traditional notion of culture, then students are likely to view the world as a place with static cultural borders that reinforce a sense of 'us' and 'them' as being separate and constantly in opposition to each other.

Language teachers are uniquely positioned to model an open and progressive world-view to students. Rather than teachers merely projecting their own views, or a particular set of values, as complete and absolute, and trying to impose them on students, teachers need to recognise the importance of developing a balanced appreciation of a multiplicity of alternative positions that can be negotiated during interaction with others. This can occur not only through direct social interaction with the cultural other, but also through intercultural engagement in classroom discussion. Identifying different ideas, points of view and attitudes may be an important first step in recognising different identity positions of different cultures. Yet, this alone risks stereotyping and essentialising the cultural other. The most important next step for more meaningful and respectful intercultural engagement is to consider commonalities between cultur- 
al groups and to negotiate new shared understandings and values. Such acts can create new and dynamic inter-cultural identity positions of shared meaning. In this way, teachers can model an open-minded world view and at the same time mediate how students see the cultural other, as is advocated by Liddicoat and Kohler (2012).

Teachers face a difficult balance in having to challenge overgeneralisations, negative stereotypes and discriminatory views. This should be done in a way that demonstrates a sensitive balance and openness to alternative views, whilst also being aware of ethical boundaries. There is tension between accepting all other positions as equally valid and judging certain positions or views as being unacceptable. This is where teachers' professional and moral judgement is needed to negotiate and raise awareness of the ethical and moral values of different positions. Before judging a position is morally acceptable or not, it is important to hear and consider a range of views as part of the process of forming judgement. This is where class discussion can be highly valuable to share a range of alternative views, to demonstrate respect for difference, to explore cultural norms, and to develop critical thinking.

For many language teachers and learners, there is still confusion between the roles of culture-related knowledge and culture-related capabilities (House 2008). In contrasting the notion of static culture as merely knowledge of the 'cultural other', Liddicoat (2002) describes a dynamic view of culture as sets of variable practices that people use to engage others. Adopting a dynamic view of culture places less emphasis on knowledge of 'the culture' whilst placing greater emphasis on being able to engage with a cultural other. Liddicoat's (2002) dynamic view of culture views interactional acts as meaningful events in which cultural norms are continually negotiated and reshaped. This is consistent with Holliday's (2011) non-essentialist view of culture that recognises complexity and unclear boundaries where diversity is the norm.

Language teachers have great opportunities to encourage critical thinking when exploring aspects of culture. Exploring the definition of culture itself can be a good starting point. Students should be invited to share their opinions of their own cultural self and to discuss how they imagine cultural others. Identities of self and other can be explored at individual and collective levels. For example, the self may be explored at various identity levels, such as the individual, the family unit, the student's class, the school community, the town's population where one lives, the province where one lives, at the national level and even as a global citizen. In fact, it is a goal of the 2013 national Indonesian 
curriculum for learners of English to develop identity positions as national and global citizens. To achieve this, students will need to constructively use their imagination and language to develop a more nuanced understanding of the notion of culture, and tolerance towards difference. For teachers, it is important to explore students' views and to treat different ways of seeing things with respect. This is a good way for teachers to model respect for difference and for diverse views. Teachers also need to demonstrate and raise awareness of the notion of a multiplicity of identity positions.

\section{CONCLUSIONS AND SUGGESTIONS}

Imagination plays an important role in intercultural dynamics. Bakhtin's (1981) notion of dialogism means that the call to respond to the other does not merely refer to the other we face in the immediate moment, but extends to the unseen other, including voices of the past and future. We are challenged to imagine how the other might respond, think or act in particular scenarios. There is a multiplicity of possibilities, as we view others at an individual and collective level who are capable of exerting agency and divergent views, rather than merely representing an essentialised static single position. Respect for different opinions reflects an ethical response to others. Dialogism as conceptualised by Bakhtin is grounded in relational processes and involves critical thinking to consider and negotiate alternative voices.

Dialogism and respect for alternative voices should be practiced in language classrooms and are consistent with the aims of the 2013 National Curriculum. If students are to truly become global citizens and agents of transformational change for a better world, they will require an understanding of other cultures but more importantly they will also need to be able to engage constructively in inter-cultural spaces.

\section{REFERENCES}

Bakhtin, M.M. (1981). The dialogical imagination: Four essays by M. M. Bakhtin. Austin: University of Texas Press..

Barclay, F. (2010). Kristeva's stranger within: The question of the foreigner in Daniel. Paragraph, 33(1), pp. 1-19. 
Brandist, C. (2002). The Bakhtin circle: Philosophy, culture and politics. Sterling: Pluto Press.

Duranti, A. (1997). Lingustic anthropology. New York: Cambridge University Press.

Holliday, A. (2011). Intercultural communication and ideology. Los Angeles: Sage.

House, J. (2008). What Is an 'Intercultural Speaker'?. In E.A. Soler \& M.P.S. Jorda (Eds), Intercultural language use and language learning (pp. 7-21). New York: Springer

Kementrian Pendidikan dan Kebudayaan. (2013). Kompetensi dasar Sekolah Menengah Atas (SMA)/Madrasah Aliyah (MA). Retrieved from http://www.google.com.au/url?sa $=\mathrm{t} \& \mathrm{rct}=\mathrm{j} \& \mathrm{q}=\&$ esrc $=\mathrm{s} \&$ frm $=1 \&$ source $=$ web\&cd $=6 \&$ ved $=0$ CEoQFjAF \&url $=$ http $\% 3 \mathrm{~A} \% 2 \mathrm{~F} \% 2$ Furip.files.wordpres s.com $\% 2 \mathrm{~F} 2013 \% 2 \mathrm{~F} 02 \% 2 \mathrm{Fkompetensi-inti-dan-kompetensi-dasar-sma-}$ rev9feb.pdf\&ei=v5aMUt3rA8XJiAe91oCADQ\&usg=AFQjCNElVaOKfQG9DPo_TxqS3y9pmXknQ

Kramsch,C. (2009). The multilingual subject: What foreign language learners say about their experience and why it matters. Oxford: Oxford University Press.

Kristeva, J. (1991). Stranger to ourselves. Hempstead: Harvester Wheatsheaf.

Liddicoat, A. (2002). Static and dynamic views of culture and intercultural language acquisition. Babel, 36(3), 4-11.

Liddicoat, A \& Kohler, M. (2012). Teaching Asian languages from an intercultural perspective: Building bridges with and for students of Indonesian. In X. Song \& K. Cadman (Eds), Bridging transcultural divides: Asian languages and cultures in global Higher Education (pp. 73-100). Adelaide: University of Adelaide Press.

Lo Bianco, J. (2009). Dilemmas of efficiency, identity and worldmindedness. In J. Miller, A. Kostogriz, \& M. Gearon (Eds), Culturally and linguistically diverse classrooms: New dilemmas for teachers (pp. 113-131).

Clevedon: Multilingual Matters, Clevedon.

Wenger, E. (1998). Communities of practice: Learning, meaning, and identity. Cambridge: Cambridge University Press. 